\title{
Thormation
}

Nordic Journal of Art and Research

ISSN: 1893-2479

www.artandresearch.info

\section{Ulikhet som impuls for nye oppdagelser i dans: Å toye både muskler og meninger gjennom mangfold $\mathrm{i}$ Danselaboratoriet}

\author{
Tone Pernille Østern ${ }^{1}$ (NTNU) og Elen Øyen (Danselaboratoriet) ${ }^{2}$ \\ Foto: Jøran Værdahl, Klipp \& Lim
}

\begin{abstract}
Sammendrag: I denne artikkelen har forfatterne fokus på hvordan ulikhet mellom mennesker kan fungere som en impuls som bidrar til meningsskaping, nye oppdagelser og transformasjon i improvisasjon i dans. Artikkelen tar utgangspunkt i Østerns avhandling "Meaning-making in the Dance Laboratory. Exploring dance improvisation with differently bodied dancers" (2009). I artikkelen vever forfatterne sammen sine ulike stemmer. Tone Pernille Østerns perspektiv er som initiativtaker og tidligere koreograf-dansepedagog i Danselaboratoriet, mens Elen Øyens perspektiv er som danser i den samme gruppen. Øyen er danser og rullestolbruker. Hovedkonklusjonen i artikkelen er at gjennom å forstå ulikhet som en verdi og impuls til å møtes og skape i improvisasjon i dans, så kan deltakerne i gruppen gjennomgå kraftfulle transformative endringsprosesser når det gjelder synet på "den andre"3. Dette har en betydning som går langt ut over det konkrete, kunstneriske undervisningsrommet. "Den andre" forstås i artikkelen som en konstruksjon som både muliggjør adskillelse og utestenging fra et fellesskap, men også som en mulighet til å forstå at "den andre" ikke nødvendigvis er, eller skal være, som meg.
\end{abstract}

Emneord: Dans i samtiden, improvisasjon, flerstemthet, dialogisk kunst, transformativ pedagogikk, refleksiv forskning.

Danselaboratoriet $^{4}$ er en dansegruppe der ulikkroppede ${ }^{5}$ dansere deltar. Ulikkroppede betyr her dansere som på ulike vis er ulike: profesjonelle, amatører, med ulike tidligere danseerfaring, med og uten

\footnotetext{
${ }^{1}$ NTNU, Program for lærerutdanning, 7491 Trondheim. E-post: tone.pernille.ostern@plu.ntnu.no.

${ }^{2}$ Danselaboratoriet, Kulturenheten v/Tilrettelagt fritid, Trondheim kommune, Dronningens gate 1, 7011

${ }^{2}$ Danselaboratoriet, Kulturenheten v/Tilrettelagt fritid, Trondheim kommune, Dronningens gate 1, 7011

Trondheim. E-post: produsent@danselaboratoriet.no.

3 "Den andre" ble opprinnelig diskutert av filosofen Emmanuel Levinas (1961/1969).

${ }^{4}$ www.danselaboratoriet.no (tilgang 24.10.2014)
} 
funksjonshemming. Alle er voksne, og gruppen er en del av Kulturenheten i Trondheim kommune. Danselaboratoriets kunstneriske leder er til en hver tid en utdannet dansekunstner og dansepedagog. Fra å være et lite prosjekt som startet som en pilot i 2001 har Danselaboratoriet utviklet seg til å bli en stabil gruppe som hvert år skaper, utøver og av og til turnerer med sine egne danseforestillinger. Sjangermessig kan arbeidet i Danselaboratoriet beskrives som tilhørende det postmoderne feltet (Novack, 1990; Rustad, 2013). Impulser fra kontaktimprovisasjon, danseimprovisasjon, performance, komposisjon og koreografi blandes, mikses og finner sin egen form. Kunstnerisk leders rolle kan forstås som å være et sted i skjæringspunktet mellom koreograf og dansepedagog (se Østern, 2014). På Danselaboratoriets hjemmesider www.danselaboratoriet.no ${ }^{6}$ ligger et stort bilde- og videogalleri, samt beskrivelse av gruppens historie og repertoar.

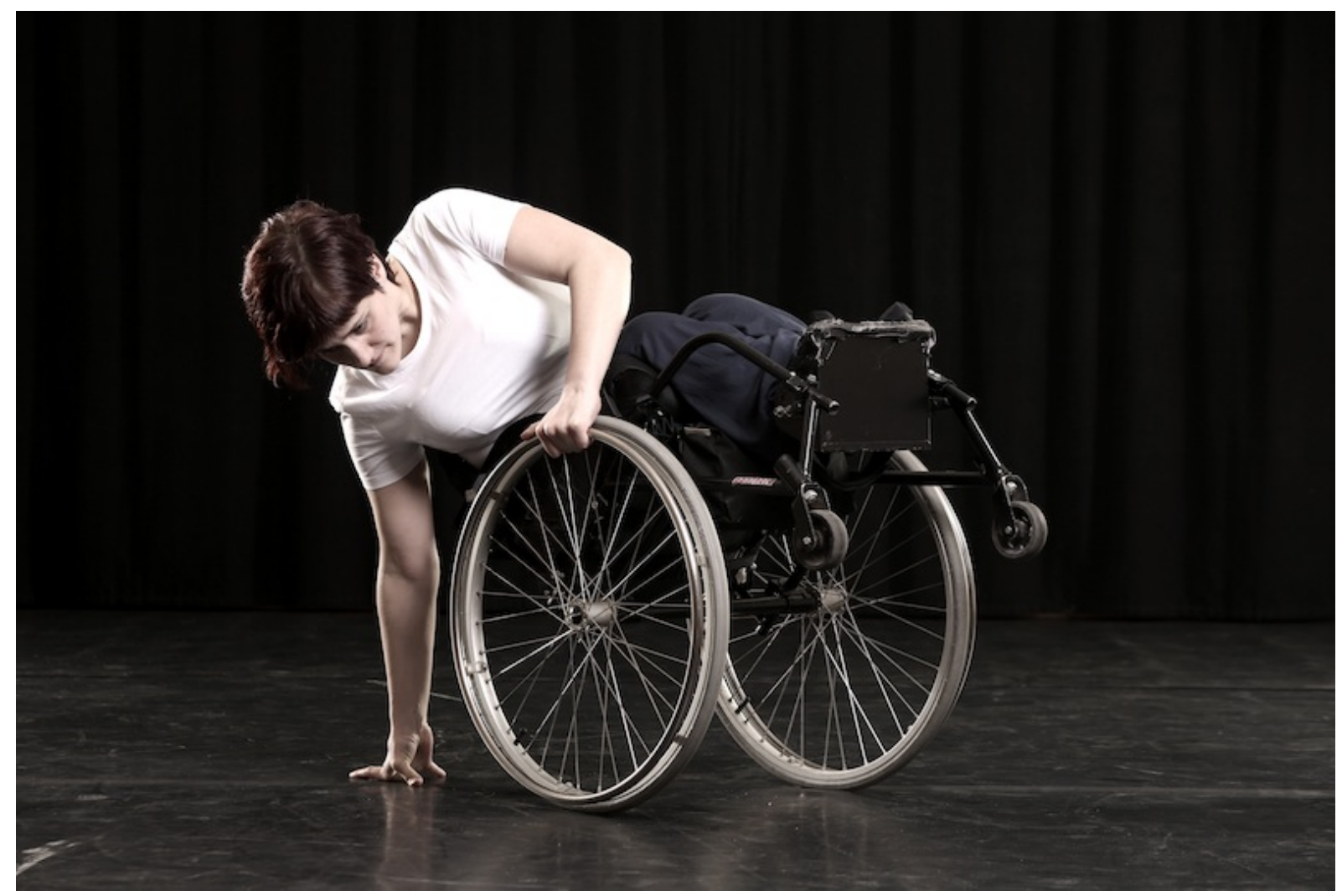

Elen Øyen i Danselaboratoriet.

\section{Plassering i feltet}

Danselaboratoriet vokste fram som en relativt ny form for dansevirksomhet i Norden, og så langt vi vet som den første i sitt slag i Norge. Fokus var fra begynnelsen på dans som kunstform. Improvisasjon og etter hvert koreografi sto sentralt, og gruppen var åpen for ulike og ulikkroppede mennesker med forskjellig livserfaring og ulik erfaring med dans. Dans med mennesker med og uten funksjonshemminger er likevel et felt innenfor samtidsdansen som har utviklet seg fra tidlig 70-tall i

\footnotetext{
${ }^{5}$ Begrepet vokste fram undervegs i Østerns PhD-arbeid, der hun sluttet å se danserne som kategorisk enten "med" eller "uten" funksjonshemming; isteden begynte hun å oppfatte dem alle som ulike og ulikkroppede, alle på sitt vis.

${ }^{6}$ (Tilgang 24.10.2014)
} 
USA, og tidlig 90-tall i Europa, og Danselaboratoriet bør forstås som en del av dette feltet og dialogen i det. Også Australia og New Zealand har markert seg med fokus på ulikkroppethet og inkludering av ulike mennesker i dans. Det finnes på internasjonal basis en rekke dansevirksomheter der mennesker med og uten funksjonshemminger deltar, fra hobbyvirksomheter til profesjonelle kompanier, vi kan bare nevne noen: Danceability $v /$ Alito Alessi ${ }^{7}$ (USA.), $\operatorname{CandoCo}^{8}$ (UK), StopGAP ${ }^{9}$ (UK), BewegGrund $^{10}$ (Sveits) og Dance Integrated Australia v/ Philip Channells ${ }^{11}$. I Norden er den finske gruppen Rajat'on (Grenseløs) den første gruppen vi vet om som fra år 2000 virket i en profesjonell kontekst med dansere både med og uten funksjonshemming. Gruppens forestilling Olotila - State of being $^{12}$ fikk enorm oppmerksomhet og ble vist mange ganger over flere år i Finland, samt i byer som Paris, Berlin og Hong Kong. For en historisk oversikt over hvordan et dansefelt med plass for ulikkroppede mennesker har utviklet seg, se f eks Adam Benjamin (2002) og Østern (2009).

\section{Forfatterstemmer}

Tone har dansefaglig og pedagogisk utdanning fra Finland, England og Sverige. Under studietiden i London i midten på 90-tallet ble hun kjent med dansekompaniet CandoCo, som var Europas første profesjonelle dansekompani med dansere med og uten funksjonshemminger. Møtet med kompaniet gjorde sterkt inntrykk og kom til å prege Tones vei videre som dansekunstner. I 2000 flyttet hun til Norge, og søkte sin vei som dansekunstner, med ønske om å skape plass i dans for andre mennesker enn den tradisjonelle kvinnelige, unge, tynne, bleke danseren. I Norge startet hun først Inclusive Dance Company ${ }^{13}$ på det frie scenekunstfeltet sammen med dansekunstnerkollega Arnhild Staal Pettersen, så kom Danselaboratoriet i samarbeid med Trondheim kommune, og videre etableringen av MultiPlié dansefestival som nå drives av DansiT, Senter for dansekunst i Sør-Trøndelag ${ }^{14}$. MultiPlié er festivalen som tøyer og bøyer ideer om hva dans er og hvem som kan være en potensiell danser og koreograf.

Danselaboratoriet startet altså som et pilotprosjekt i 2001. Fra 2003 startet gruppen på permanent basis; da både som et kunstnerisk prosjekt med støtte fra Trondheim kommune, samt som forskningsprosjekt for Tones (Østern, 2009) PhD-studier i dansekunst ved Teaterhögskolan i Helsingfors. Med Danselaboratoriet ønsket Tone å utforske kunstnerisk hva dans kan være, i møtet mellom ulike dansere som blir gitt en likeverdig plass i dansestudioet og på scenen. Dermed ble prosjektet etablert som et satsingsprosjekt ved Kulturenheten i Trondheim kommune, i 2003 med kun 2 deltakere. Interessen for prosjektet var laber i begynnelsen, men vokste raskt ${ }^{15}$. Når denne artikkelen ble skrevet hadde Danselaboratoriet en kjerne av tolv dansere som har vært med i lang tid. Tone er ikke lenger kunstnerisk leder for gruppen ${ }^{16}$.

Elen Øyen ble med i Danselaboratoriet i 2005. Hun er utdannet barnevernspedagog og hadde da hun startet ingen erfaring med dans (å få innpass i dansevirksomhet er vanskelig både på amatør- og

\footnotetext{
${ }^{7} \mathrm{http}: / / \mathrm{www}$. danceability.com/ (tilgang 24.10.2014)

8 http://www.candoco.co.uk/ (tilgang 24.10.2014)

9 http://stopgap.uk.com/ (tilgang 24.10.2014)

${ }^{10} \mathrm{http}: / /$ www.beweggrund.org/ (tilgang 24.10.2014)

11 http://philipchannells.com/ (tilgang 24.10.2014)

12 Se for eksempel http://tkm.fi/ihan_epanormaalia_multimedia/en/?p=179 (tilgang 24.10.2014)

13 www.dance-company.no (tilgang 24.10.2014)

14 www.dansit.no (tilgang 24.10.2014)

${ }_{15}$ Les mer om utviklingen av prosjektet i Østern, 2009.

${ }^{16}$ Ingeborg Dugstad Sanders er fra år 2012 kunstnerisk leder for Danselaboratoriet på fast basis, og hun var også vikarierende kunstnerisk leder år 2010-11.
} 
profesjonelt nivå i Norge for mennesker med funksjonshemming). Hun ble likevel fort en dedikert danser i gruppen, og har når denne artikkelen skrives deltatt som skapende og utøvende danser i nesten 10 år, med blant annet helkveldsforestillingene Ønskes: kjcerlighet (2006, 2007), Kodenavn dans (2007), DA:FU (2008); Kropp a'long (2009), SPAGAT (2010, 2011), Den indiske prinsesse (2011), Søtt, surt og fortalt (2012), PERFECT (im)PERFECTIONS - stories untold (2014), samt en rekke kortere stunts, improvisasjoner og fremføringer. I 2011 ble hun også produsent for gruppen, ansatt av Trondheim kommune i $20 \%$ stilling. Hun har i tillegg deltatt som assisterende lærer for Danselaboratoriet ved en rekke kurs, seminarer og konferansen i inn- og utland. Fra 2009 har Elen og Tone undervist sammen ved en rekke anledninger innenfor lærerutdanning, samt skrevet sammen (Østern \& Øyen, 2014, 2015).

I denne artikkelen vever vi sammen våre stemmer basert på våre erfaringer med Danselaboratoriet fra ulike ståsted. Vi har fokus på hvordan ulikhet kan forstås som en impuls for meningsskaping i danseimprovisasjon, og hvordan dette kan lede til transformativ læring hos danseredeltakere og kunstnere-pedagoger. Vi har i artikkelen særlig fokus på endret forståelse av felleskap og "den andre" i Danselaboratoriet. Diskusjonen om "den andre" (the Other) i motsetning til "det egne" kommer opprinnelig fra filosofen Emmanuel Levinas (1961/1969). Vi forstår i korthet begrepet "den andre" som en konstruksjon som både muliggjør utestenging og utenforskap av "annerledes" grupper og individer, men også som en mulighet å forstå at "den andre" ikke nødvendigvis er, eller skal bli, som jeg.

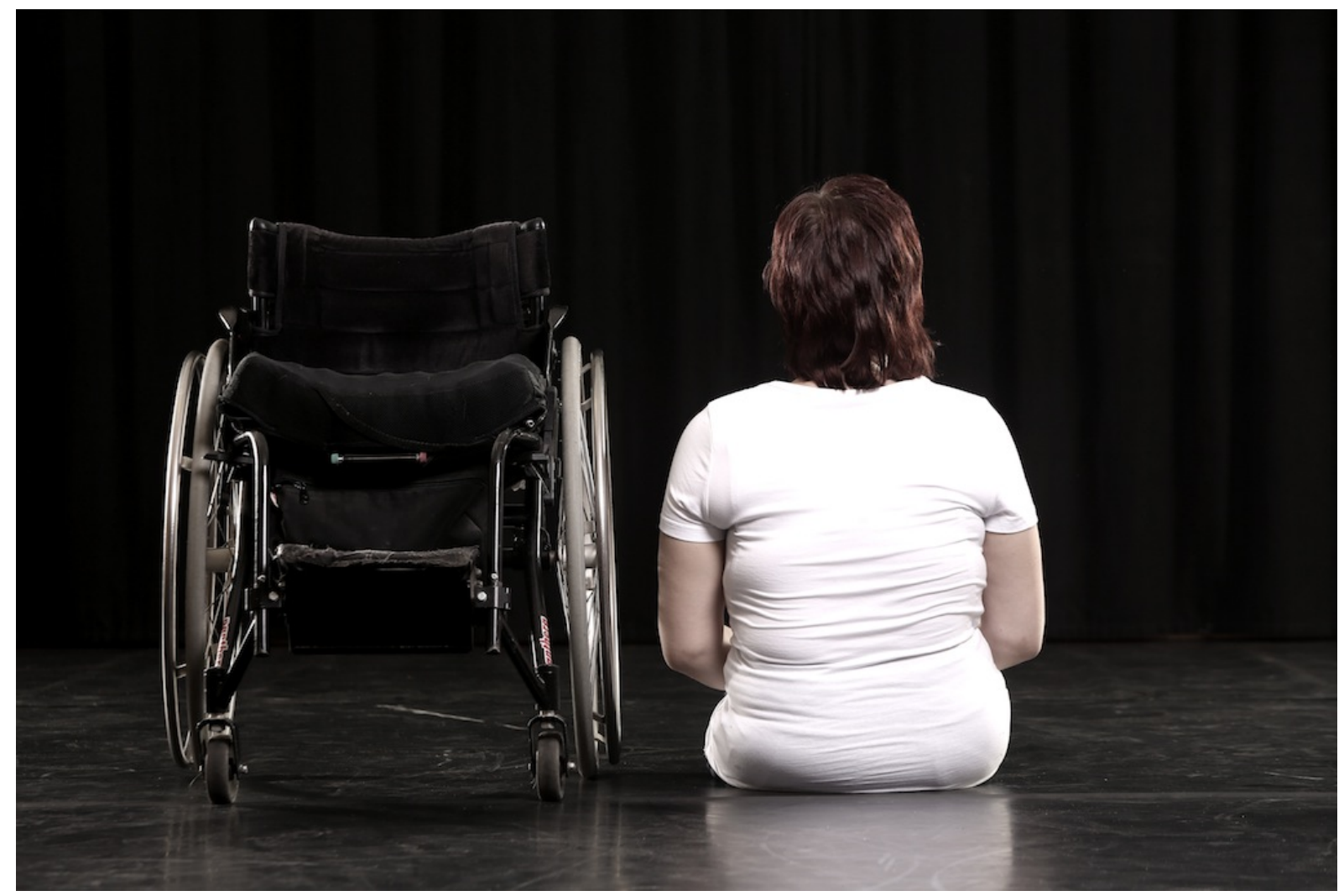

"Den andre"?

Østerns (2009) avhandling danner bakgrunn for artikkelen. I doktorgradsprosjektet fulgte Østern åtte dansere og deres endringsprosesser i Danselaboratoriet gjennom det første året de deltok i gruppen. 
Det empiriske materialet består av individuelle intervjuer før, midt i og etter avsluttet år (2003-04) i Danselaboratoriet med alle åtte dansere, video-observasjoner gjort av en ekstern videokunstner (200304), samt forskerlogger og evalueringer gjort av en rekke dansere gjennom årene 2003-2009.

Hva betyr det så at ulikhet fungerer som en impuls til meningsskaping og nye oppdagelser i improvisasjon i dans? I en evaluering av Danselaboratoriet høsten 2006 skrev Elen følgende. Elen var da danser i gruppen, mens Tone var koreograf-dansepedagog:

Et øyeblikk som jeg husker spesielt godt er når Tone og jeg improviserte foran de andre. Plutselig stjal hun en del av rullestolen min! Det var hysterisk morsomt, men min spontane reaksjon var: "Men nei! Hun kan ikke bare gjøre det!". Den reaksjonen gjorde at dansen ble veldig ekte. I tillegg, som jeg allerede sa, så var det utrolig morsomt! Tones handling og min reaksjon skapte en dialog mellom oss som vi kunne bygge masse videre på”. (Elen i skriftlig evaluering av Danselaboratoriet, høsten 2006)

I sin avhandling (Østern, 2009) skriver Tone følgende (oversatt fra engelsk til norsk) om samme situasjon sett fra sitt ståsted som koreograf-dansepedagog:

Når jeg leser sitatet av Elen, så husker jeg vår duett veldig godt. Jeg husker spesielt det øyeblikket da jeg stjal den ene delen av hennes rullestol. [...] Mens jeg satt der, forflyttet Elen vekten av sin kropp over på ene siden av rullestolen, strekte ut en arm mot meg og gikk inn i et full sidelening, der hun støttet seg på den andre armen og det ene rullestolhjulet, mens det andre hjulet spant rundt i luften. Hjulet spant med en behagelig tikking. Det snurrende hjulet ble for fristende å stjele, og isteden for å ta hennes utstrakte hånd, som var en invitasjon til meg, så lente jeg meg framover og klikket ut hjulet av låset. Jeg kan fortsatt høre klikkinga da låset åpnet seg. Med rullestolhjulet i mine hender, så vi på hverandre gjennom det metalliske hjulgitteret. I vår øyekontakt gjennom gitteret kunne jeg kjenne energien mellom oss stige. Elen så overrasket ut og et stort smil brast ut i ansiktet hennes. Hun skled ut av rullestolen og ned på gulvet, tvilte et øyeblikk, men lente seg så framover for å ta bort også det andre hjulet fra rullestolen sin. Jeg hørte et nytt klikk. Derfra fortsatte vår duett med Elen, meg og den demonterte rullestolen. (Tone, i Østern, 2009, 58)

Dette møtet mellom oss i danseimprovisasjon er et eksempel på hvordan ulikheten mellom oss blir brukt som impuls til meningsskaping og nye oppdagelser. Rullestolen blir ikke noe som er i veien, til bryderi eller noe som hindrer til deltakelse. Tvert imot, så blir rullestolen gjenstand for utforskning, den blir skilt fra Elen som person, den blir dekonstruert og brukt på nye måter. Dermed får rullestolen nye betydninger og møtet mellom oss blir ekte fordi det inneholder et moment av risiko. Vi bryter også et tabu, i og med at rullestolen ikke behandles som noe man skal late som ikke er der; noe man ikke får snakke om eller gjøre noe med. I stedet bruker vi stolen på uventede måter til å skape selve dansen som danses. Ingen av oss, verken koreograf-pedagog eller danser, vet hva som skal skje etter at hjulene er tatt bort fra rullestolen. Vi vet bare at nye muligheter åpner seg i en dialog der vi begge er like viktige og avhengige av hverandre. Vi vil understreke at det å bryte tabuer på denne måten var mulig fordi det allerede fantes en trygghet mellom oss som vi hadde opparbeidet gjennom mange timers improvisasjon sammen. Vi visste hvor vi hadde hverandre, og det var dags å bryte noen grenser. 


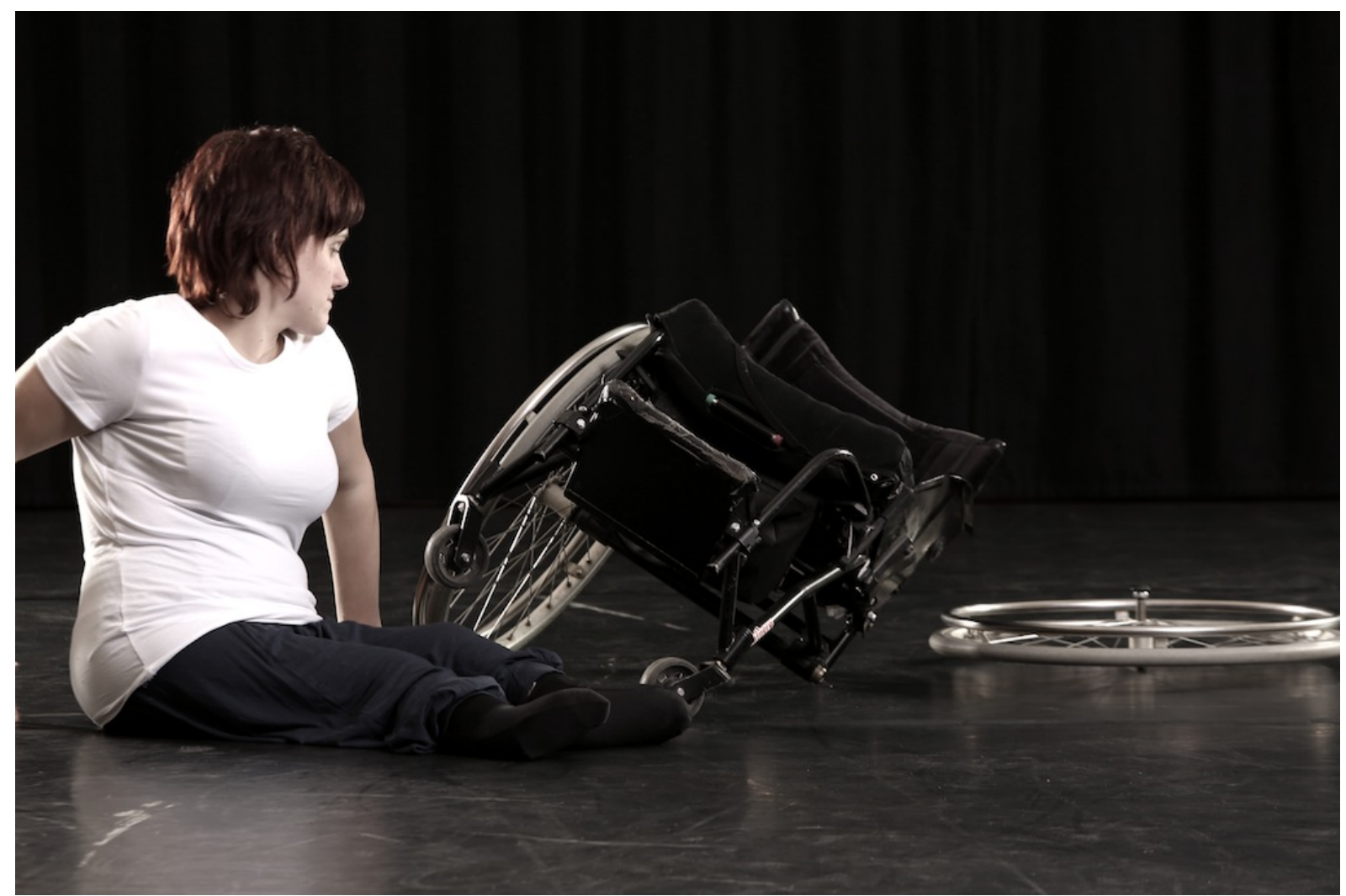

A demontere en rullestol og dekonstruere ideer om hva dans kan vare.

Fallhøyden i improvisasjon er stor, på grunn av høy risiko i møtet med det uventende. Møtet med det ukjente stiller høye krav til koreografen-pedagogen for at ikke alt skal gå galt under improvisasjonen. I frie landskap er det veldig lett at stereotypier gjentar seg. Men med bevissthet og mot basert på et inkluderende verdigrunnlag kan man igangsette virkelig transformative prosesser der ny mening og forståelse skapes. Danselaboratoriet er et prosjekt hvor slike forandringsprosesser har skjedd utfra flere ulike aspekter (se Østern, 2009). I denne artikkelen skal vi holde fokus på forandringsprosesser i forhold til fellesskap og synet på "den andre", selv om også mange andre endringsprosesser fant sted i prosjektet.

\section{Elen - en danser}

Elen er rullestolbruker på grunn av ryggmargsbrokk. Når hun vurderer og artikulerer dansekunsten/dansepedagogikken og endringsprosessene i Danselaboratoriet, skjer dette med erfaringer fra egen skolegang som bakteppe. Gjennom skolegangen fikk hun befestet et selvbilde preget av å være "den andre" - et selvbilde som har satt seg i ryggmargen. Samtidig har hun også gode minner om den inkluderende lærer. Elen forteller:

Gjennom hele grunnskolen hadde jeg mange assistenter i gymtimene. Noen bra. Men jeg har også hatt veldig mange negative opplevelser. På barneskolen opplevde jeg veldig ofte å stå på sidelinja å kaste ball sammen med en assistent (ofte ufaglært), mens resten av elevene spilte fotball og lignende. Det ble gjort noen spinkle forsøk på å inkludere meg, men for meg opplevdes det som litt "fiktive" forsøk. Bruke badminton-racket til å spille fotball med var ett eksempel. Det ble som regel lagd et helt spesielt opplegg for meg, i stedet for at læreren satte i gang aktiviteter hvor alle deltok på like premisser. 
På ungdomsskolen var jeg maks heldig med alle lærere jeg hadde. Etter årene på barneskolen med mange opplevelser av å være "den andre", opplevde jeg nå å ha et helt team av lærere som virkelig samarbeida om å inkludere meg og å få opp selvfølelsen min og mestringsfølelsen min.

Dette gjaldt spesielt i gym: Aktivitetene i gymmen var stort sett bygd opp sånn at alle kunne være med. Det hendte også at jeg var alene med assistent der, men jeg kan ikke huske at det skjedde ofte. Læreren la av og til opp undervisninga sånn at elevene kunne prøve rullestolen min i ulike gymøvelser. For eksempel basketball. Elevene fikk da kjenne på hvordan det er å sitte i rullestol, og de fikk se hvordan jeg bevega meg på gulvet, uavhengig av rullestolen min. De fikk også prøve sittevolleyball. Alle satt selvfølgelig på gulvet, og jeg kunne da delta på like premisser som de andre elevene.

Et spesielt umyndiggjørende minne er da alle elever på 3. trinn på VGS skulle på tur til Trondheim. Ledelsen på skolen hadde da ansatt en assistent, som hele dagen skulle følge meg og en jente i klassen min som var blind. Denne assistenten var for det første ansatt uten at jeg og den andre jenta ble spurt om det var nødvendig. Noe det ikke var, for vi begge var selvstendige personer, og gode venninner som lett kunne hjelpe hverandre ved behov. Denne assistenten var helt ufaglært, og på vår alder. Altså veldig ung. Hun fotfulgte oss over alt, og snakka til oss som om vi var femåringer. Hun traff noen kjentfolk. Da ignorerte hun oss fullstendig og oppførte seg veldig "kult" overfor de hun traff. Hun introduserte oss til noen, på en veldig nedverdigende måte. Hun brukte nærmest barnespråk til oss i andres nærvær, og syns tydelig hun var mye bedre enn oss. Vi var bare noen hun skulle passe på den dagen.

I sine livsfortellinger setter Elen fingeren på hvordan opplevelsen av å være "den andre” og noen som er utenfor fellesskapet setter seg i kroppen gjennom å alltid få individuelt spesialprogram. Følelsen av umyndiggjøring og krenkelse skjer når beslutninger blir tatt over hodet på en. Men Elen peker også på hvordan den inkluderende lærer istedenfor å segregere "den andre" tør å forandre selve faget som skal undervises og læres, slik at faget åpnes for et mangfold av elever. Man kan spille volleyball sittende på rumpa. Man kan danse også uten bein. Det er nettopp dette fokusskiftet som er sentralt i Danselaboratoriet. Det er dansen, altså faget, som skal åpnes opp for nye måter å danses på, istedenfor at de ulike og ulikkroppede elevene skal presses inn i eksisterende, allerede etablerte og ofte begrensende danseriske, estetiske sjangerrammer. Elen skriver om hvordan denne måten å jobbe pedagogisk og kunstnerisk virker på henne:

I samfunnet hersker det gjerne en oppfatning om at folk med funksjonshemming er skjøre, og tåler mindre enn folk uten funksjonshemming. Jeg er vant til å bli behandla med silkehansker, og folk vil være veldig forsiktige med meg. Mange blir usikre i møte med meg. På hva jeg tåler, hva de kan gjøre sammen med meg og ikke, og hva de ikke kan gjøre. Mange er redde for å spørre om ting som har med funksjonshemminga mi å gjøre, det har jeg også opplevd i Danselaboratoriet. Men i motsetning til i samfunnet ellers, skapes det i Danselaboratoriet trygge rammer for å utprøve grenser for hva jeg og kroppen min kan gjøre. Det er tatt utgangspunkt $\mathrm{i}$ at jeg kan, og at jeg kjenner meg selv. Folk kan være usikre når de kommer til Danselaboratoriet, på hva jeg som danser med funksjonshemming kan gjøre. Men gjennom ulike øvelser blir det synliggjort at jeg kan delta på lik linje med de andre. Jeg trenger ikke å argumentere med ord til folk for alt jeg kan. Det blir vist ved hjelp av kroppen. Det blir fra første stund tatt utgangspunkt i at jeg selv klarer å sette grenser for hva jeg tåler og kan gjøre. Jeg blir myndiggjort. Dermed blir ikke folk så redd for å prøve ut ting sammen med meg, eller spørre meg hvis de lurer på noe. 


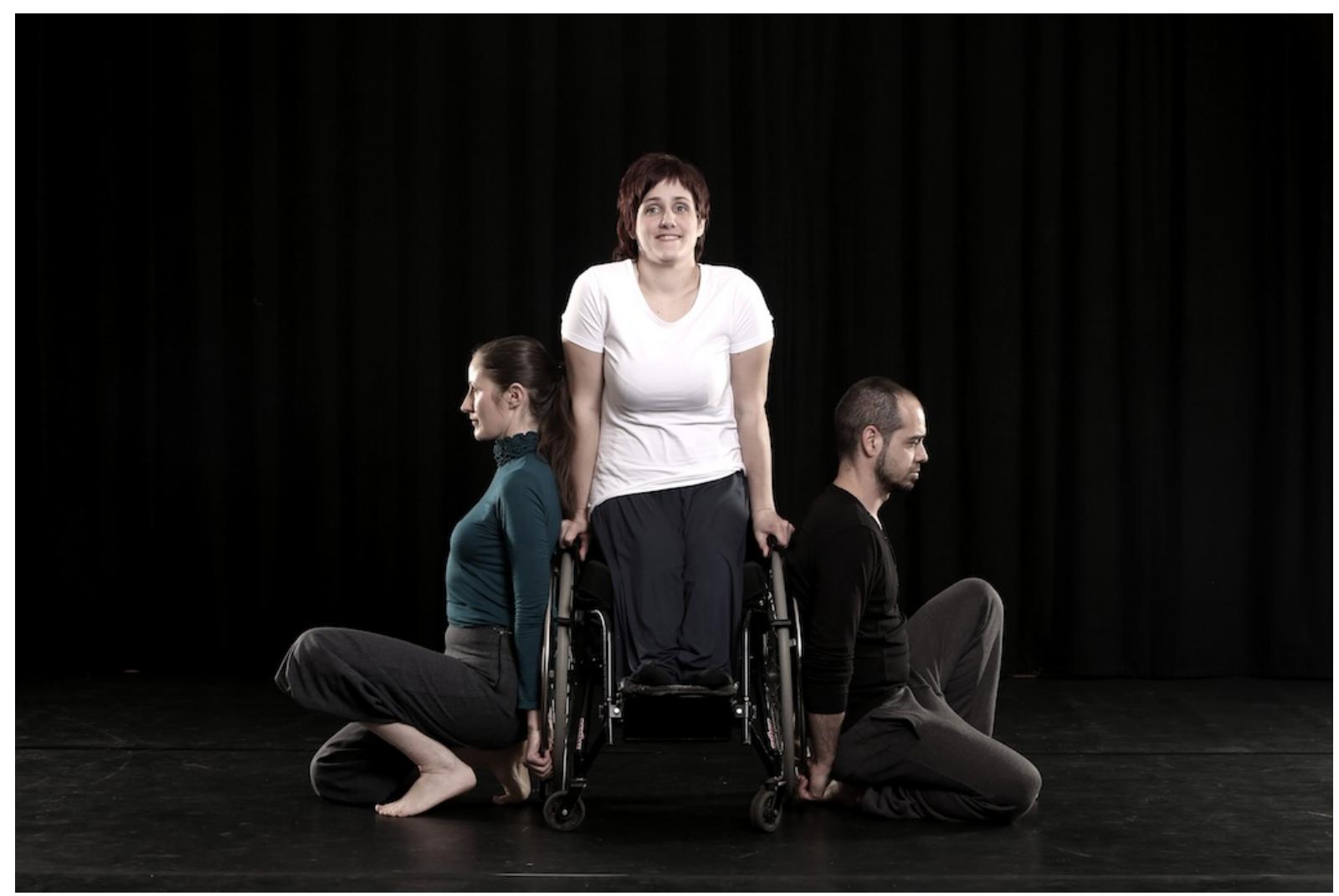

Dans på kryss og tvers av ulikhet blant danserne.

I det følgende skal vi definere vår forståelse av meningsskaping og improvisasjon før vi presenterer hvordan de 8 dansernes syn på felleskap og "den andre" ble forandret i løpet av år 2003-04 med Danselaboratoriet.

\section{Meningsskaping}

Innenfor rammene av en hermeneutisk-fenomenologisk vitenskapsteoretisk posisjonering, og som et resultat av Østerns studie (2009), definerer vi meningsskaping i denne konteksten som en kroppslig, mobil og transformativ prosess. Den meningsskaping som skjer i Danselaboratoriet avhenger av deltakernes kroppslige opplevelser og erfaringer med danseimprovisasjon sammen med de andre danserne. Jack Mezirow $(1991,34)$ definerer meningsperspektiv som en persons referanseramme som all mening konstrueres gjennom. Dette referansesystemet fungerer som et slags taust trossystem eller paradigme for personen. Mezirow $(2006 / 2008$, 27) forklarer hvordan meningsperspektiver fungerer som tankevaner (habits of mind) og at en person lærer gjennom de meningsperspektivene hun besitter. Disse meningsperspektivene kan også sammenlignes med det fenomenologiske konseptet livsverden (lifeworld), som Edmund Husserl (1970) beskriver som the world of immediate experience. For eksempel vil mange mennesker uten funksjonshemming på en taus, umiddelbar måte automatisk klassifisere seg selv som en hjelper til et menneske med funksjonshemming. Dette er en tankevane som hindrer likeverdige dialoger.

Carrie Sandahl og Philip Auslander $(2005,129)$ skriver om hvordan medisinske definisjoner av funksjonshemming dominerer til tross for mer enn 30 års aktivisme for å hevde en minoritetsidentitet for mennesker med funksjonshemming. Medisinen har definert mennesker med funksjonshemming som en problempopulasjon. Deres kropper har behov for korreksjon og hjelp, og de blir forstått som 
pasienter. Når dette synet strekker seg ut over legekonsultasjoner og inn i hverdagsmøter mellom mennesker med og uten funksjonshemming, skapes en umyndiggjørende og infantiliserende relasjon. Dette er ofte det virkelig store problemet for mennesker med funksjonshemming, ofte langt større en selve funksjonshemmingen.

I denne artikkelen definerer vi mennesker med funksjonshemming som en minoritet, istedenfor som pasienter. Det betyr at i Danselaboratoriet, som består av dansere med og uten funksjonshemming, møtes majoritet og minoritet. Tradisjonelt er det majoriteten som har makt til å definere identiteten og kapasitetene til minoriteten. Danselaboratoriet prøver å destabilisere denne situasjonen gjennom å la minoritets- og majoritetsstemmer komme likeverdig til uttrykk gjennom reelle dialoger der evnen til å virkelig lytte øves opp kroppslig og verbalt. En slik destabilisering konfronterer alle med sine perspektiver på kropp, dans og "den andre". Å få til en slik destabilisering krever pedagogisk og koreografisk bevissthet, og mot av alle involverte, men det åpner også for meningsskaping.

Ifølge Mezirow (1991, 93-94) skjer læring gjennom forandring og transformasjon. I sin transformative læringsteori presenterer han fire ulike måter som voksne lærer på, i ett spekter fra forandring innenfor en persons eksisterende meningsperspektiver, til fundamental transformasjon av meningsperspektiver. Her presenterer vi kun den siste, mest omveltende formen for læring, siden flere av de åtte danserne i forskningsprosjektet (Østern, 2009) gjennomgår denne formen for transformasjon av meningsperspektiver i synet på felleskap og "den andre" mens de deltok i Danselaboratoriet. Transformasjon av meningsperspektiver forklarer Mezirow slik:

This means becoming aware, through reflection, of an incomplete meaning perspective and then transforming that perspective through a reorganization of meaning. This type of learning begins with experiences that fail to fit a learner's expectations and thereby lack meaning. This is the most significant kind of emancipatory learning. (Mezirow, 1991, 93-94)

Også den engelske koreografen og dansepedagogen Benjamin (2002), tidligere kunstnerisk leder i CandoCo Dance Company, vektlegger endring og transformasjon når han sier at dans i møtet mellom dansere med og uten funksjonshemming "is not only about stretching your muscles, but also about streching your mind". Det er altså ikke bare musklene som strekkes i dans i møtet mellom ulike mennesker, men også tankene, ideene og meningene. Å lære å se verden og andre mennesker på en ny måte handler om å tillate seg å virkelig bli "strekt" og forandret i møtet med det ukjente. Improvisasjon som sjanger $\mathrm{i}$ dans har en viktig funksjon $\mathrm{i}$ å åpne opp for disse transformative, meningsskapende prosessene i Danselaboratoriet.

\section{Improvisasjon i dans}

Improvisasjon er et møte med det ukjente. Når man improviserer i dans blir man gjerne utfordret og konfrontert med ukjente sider ved både dansen, seg selv og dem man improviserer sammen med eller for. Elen skriver om ett av sine første møter med improvisasjon:

Lenge var det helt umulig for meg å tenke meg at jeg skulle improvisere, finne opp dansen mens jeg holdt på å lage min egen koreografi. Jeg trodde man måtte være utdanna danser for å gjøre sånt, og at det fantes en "riktig" måte å danse på. En dag ble jeg spurt om jeg hadde lyst til å vise improvisasjoner i en forestilling vi skulle sette opp. Vi var fire helt forskjellige personer som skulle vise hver vår lille improvisasjon. Mitt første instinkt var å si "nei, dette klarer jeg ikke!". Jeg tror kanskje jeg sa det et par ganger og. Men igjen føltes det som et nederlag å si nei. Jeg ble utfordra på å ta en liten improvisasjon foran resten av gruppa, og hadde hjertet i halsen. Da jeg var ferdig fikk jeg applaus! Til min store overraskelse var det til og med noen som sa de syns det var kjempefint! Siden det øyeblikket har improvisasjon vært 
det jeg brenner aller mest for i dansen. Det kan ikke bli feil, og man kan bruke seg selv uendelig. Kroppen, tankene og følelsene mine har uante muligheter for å få til dans. Og om jeg sitter i rullestol eller ikke spiller ingen rolle. Jeg er meg, og jeg kan improvisere. Og dette får publikum se, og kan ikke argumentere for at jeg er "noe annet". Folk får se med egne øyne at jeg kan bruke meg selv uten å måtte ha noen form for spesialopplegg. Jeg bruker mine egne forutsetninger, akkurat sånn som alle de andre. Og dansen min blir like fullverdig som de andres.

Noen øyeblikk i improvisasjon kalles av Nancy Stark Smith (1987, 3), en av de opprinnelige kontaktimprovisatørene som jobbet sammen med Steve Paxton ${ }^{17}$, "the gap". Dette forklarer hun som "the spot where you are when you don't know where you are":

Where you are when you don't know where you are is one of the most precious spots offered by improvisation. It is a place from which more directions are possible than anywhere else. I call this place the Gap. The more I improvise, the more I'm convinced that it is through the medium of these gaps - this momentary suspension of reference points - that comes the unexpected and much sought after "orginial material" (Stark-Smith, 1987, 3).

I sin transformative læringsteori beskriver Mezirow (1991) på en lignende måte hvordan transformativ læring innebærer en prosess som starter med ett desorienterende dilemma. Dette dilemmaet - i Elens eksempel utfordringen med å improvisere innenfor rammene av en forestilling - leder til en destabilisering eller ubalanse. Denne ubalansen (rent kroppslig erfart som å falle inn i et gap under improvisasjon, jfr. Stark-Smith, 1987) inneholder muligheten til å skape nye meningsperspektiver. Den prosess som settes $\mathrm{i}$ gang av å møte et desorienterende dilemma kan også forstås som en problemløsende prosess. Benjamin (2002, 49-61) løfter fram problemløsing som et nøkkelbegrep innenfor danseimprovisasjon. Et problem oppstår når du møter noe du ikke er kjent med: For eksempel en rullestol, eller å skulle stå på hendene. Improvisasjon konfronterer deg med problemer og paradokser som kanskje til syvende og sist ikke finnes "der ute", men oppstår "der inne" i deg, fordi det ukjente ikke passer inn i din personlige referanseramme eller tause trossystem. Elen forteller om da hun ble utfordret til å stå på hendene. Det var for henne et møte med det ukjente, og passet ikke inn i hennes tause trossystem om hva hun er kapabel til:

Som rullestolbruker er jeg vant til at det finnes etablerte oppfatninger om hva jeg kan gjøre og ikke. Det er helt selvsagt at en rullestolbruker ikke kan stå på hendene, som de andre gående kan gjøre! Dette ble kraftig motbevist på en øving. Jeg hadde ikke en gang tenkt tanken selv, før kunstnerisk leder foreslo at jeg kunne prøve. Dette året hadde jeg spesielt god kontakt med en av danserne. Hun stilte velvillig opp og prøvde å finne ut sammen med meg hvordan vi kunne løse dette. Jeg la meg på magen gulvet, og støtta meg på hendene. Den andre danseren tok tak i anklene mine og løfta beina mine helt opp. Plutselig sto jeg på hendene, kroppen min var opp ned og loddrett, og jeg så verden helt fra et annet perspektiv enn jeg noen gang hadde gjort. Mange konvensjoner om hva en rullestolbruker er, var kasta ut vinduet!

For at improvisasjon skal fungere som improvisasjon, må det undervises og utøves innenfor, og samtidig utvikles, et problemløsende ethos. Ethos er gresk, og betyr omtrent "etisk holdning". $\AA$ improvisere krever også mot, både av eleven og ikke minst av pedagogen eller koreografen. Å la seg falle inn i mellomrommet der man som underviser "er der man ikke vet hvor man er" er likevel både kunstneriske og pedagogiske øyeblikk da man har mulighet å skape andre og bedre måter å undervise, relatere og lytte på.

\footnotetext{
${ }^{17}$ Kontaktimprovisasjon er en egen form for improvisasjon som utviklet seg i USA fra rundt starten av 1970tallet. Steve Paxton regnes som kontaktimprovisasjons grunnlegger. Se for eksempel Cynthia Novack, 1990; Hilde Rustad, 2013.
} 


\section{Meningskonsentrering}

Analysen av de 8 dansernes meningsskapende prosesser i doktorgradsprosjektet (Østern, 2009) skjedde med inspirasjon av Amadeo Giorgis (1985) metode for fenomenologisk meningskonsentrering. Intervjumaterialet ble kondensert til et antall meningstemaer som videre ble fortettet til seks meningsperspektiver. Østern konstruerte gjennom denne prosessen et kroppslig, eksistensielt, subjektivt, fellesskaps-, estetisk respektive didaktisk meningsperspektiv som de åtte danserne reflekterte fra og gjennom når de fortalte om sine opplevelser i Danselaboratoriet (se Østern, 2009, for en mer utførlig beskrivelse). I denne artikkelen holder vi kun fokus på hvordan meningsperspektivet "fellesskap" (oversatt fra "the community meaning perspective") ble forandret hos danserne. Med dette mener vi deres syn på "den andre", på fellesskapet og på seg selv som en del av fellesskapet. Beskrivelsen av analysen og fortolkningen vil på grunn av denne artikkelens lengde kun skje kortfattet.

\section{Meningsperspektivet "fellesskap" i endring}

Vi presenterer først de åtte danserne (samt pedagogen) som deltok i Danselaboratoriet som forskningsprosjekt for Østerns PhD-avhandling i 2003-04. Elen hadde ikke startet i Danselaboratoriet ennå. Alle danserne, bortsett fra Tone, har fiktive navn:

Paul - profesjonell danser uten funksjonshemming som hadde flyttet til Trondheim fra et annet kontinent samme år. I 2004 var han 33 år gammel. Han hadde jobbet mye med improvisasjon i sitt hjemland. Han snakket nesten ikke norsk eller engelsk i det første intervjuet høsten 2003 og verbal kommunikasjon var da et problem. Ved det tredje intervjuet sommeren 2004 hadde han rukket å bli temmelig god i norsk.

Karen - blind danser som ikke jobbet profesjonelt med dans. I 2004 var hun 26 år gammel. Hun hadde ingen tidligere erfaring av danseimprovisasjon da hun startet i Danselaboratoriet.

Mona - danser uten funksjonshemming som ikke jobbet profesjonelt med dans. I 2004 var hun 31 år gammel. Hun hadde noe erfaring med samtidsdans før hun startet $\mathrm{i}$ Danselaboratoriet.

Heidi - fulltidsdansestudent uten funksjonshemming. I 2004 var hun 26 år gammel. Hun hadde ganske mye danseerfaring, men lite erfaring med improvisasjon før hun startet $\mathrm{i}$ Danselaboratoriet.

Anna - profesjonell danser uten funksjonshemming. I 2004 var hun 26 år gammel. Hun hadde utstrakt erfaring som dansekunstner og -pedagog da hun startet i Danselaboratoriet.

Teresa - fulltids dansestudent uten funksjonshemming. I 2004 var hun 20 år gammel. Hun hadde ganske mye danseerfaring, men lite erfaring med improvisasjon før hun startet $\mathrm{i}$ Danselaboratoriet.

Vera - danser med cerebral parese som ikke jobbet profesjonelt med dans. Vera er rullestolbruker. I 2004 var hun 24 år gammel. Hun hadde noe erfaring med danseimprovisasjon før hun startet i Danselaboratoriet. Vera har begrenset verbalt språk, noe som gjorde at intervjuene med henne hadde begrenset verdi. Deltakende observasjon og videoobservasjon var mer informativt.

Ida - fulltids dansestudent uten funksjonshemming. I 2004 var hun 24 år gammel. Hun hadde ganske mye danseerfaring, men lite erfaring med improvisasjon før hun startet $\mathrm{i}$ Danselaboratoriet.

Tone - dansepedagogen, koreografen og PhD-studenten. Tone har ingen funksjonshemming og hun var i 200433 år gammel. Hun hadde utstrakt erfaring som dansekunstner og -pedagog da hun startet Danselaboratoriet. 
Før de åtte danserne startet i Danselaboratoriet fikk de følgende tre spørsmål i et individuelt intervju:

1. Hva er din bakgrunn i dans?

2. Fortell om din relasjon til dans. Hva betyr dans for deg?

3. Fortell hvorfor du har lyst å delta i Danselaboratoriet.

I intervjuet nevnte Mona, Ida, Heidi, Teresa og Paul grunner som har med fellesskap å gjøre som en av grunnene til hvorfor de ville starte i Danselaboratoriet. De sa bl.a.:

Jeg har ikke tenkt så mye på det faktum at det er funksjonshemmede mennesker i gruppen når jeg bestemte meg for å bli med, men jeg vet at du ikke kommer til å gjøre dette til et handikappkurs [Mona hadde kjennskap til Tone som dansepedagog i samtidsdans og som koreograf]. Det er viktig at ulike mennesker ikke blir sett på som hindringer i prosjektet, men som interessante bidragsytere. (Mona)

Dette prosjektet tar bort den der "statusgreien" mellom ulike mennesker. (Ida)

Det er veldig spennende at det er så mange forskjellige mennesker i prosjektet. (Heidi)

Det er spennende med møter mellom så mange ulike mennesker. (Teresa)

Jeg syns at alle kan danse. Dans er viktig for alle, det er ikke viktig med ulike kropper. (Paul)

Disse uttalelsene ble samlet under meningsperspektivet "fellesskap", og dette var et perspektiv som Østern fulgte for å se hvordan det eventuelt forsvant, utviklet eller forandret seg i løpet av året i Danselaboratoriet. Analysen viser at den forandring og den læring som skjedde vedrørende meningsperspektivet "fellesskap" var en virkelig "wow-faktor" i Danselaboratoriet. Relasjonen mellom "meg" og "den andre" var under kraftfull transformasjon gjennom prosjektet. Dette gjelder spesielt Mona, Ida, Heidi og Teresa. Det meningstema som har gjennomgått størst transformasjon innenfor meningsperspektivet "fellesskap" er deres syn på mennesker med funksjonshemming. Dette skjer som en total dekonstruksjon av deres tidligere syn på mennesker med funksjonshemming. I takt med at de ulike danserne i Danselaboratoriet strekker seg ut og relaterer og rører ved hverandre i dans, både konkret og metaforisk, så kollapser umiddelbart de umyndiggjørende "habits of mind" vedrørende funksjonshemming som flere av danserne uten funksjonshemming på en taus måte har hatt. Dette tar seg uttrykk i blant annet følgende utsagn i intervju 3:

Når jeg prøver å fortelle om mine opplevelser for andre mennesker utenfor gruppen, så får umiddelbart det med funksjonshemming veldig mye fokus. Hvis ikke jeg hadde vært del av denne gruppa så hadde jeg sannsynligvis reagert på samme måte selv. Men nå er mine opplevelser annerledes. [...] Dette prosjektet handler ikke om funksjonshemming, det handler om dans. Det er fascinerende at vi er like i dansen. Det er ikke sånn at noen dansere er mer verdifulle enn andre. Jeg har blitt mindre forsiktig med funksjonshemmede. (Mona)

Det er spennende å prøve andre menneskers utgangspunkt, som å prøve rullestoler eller å danse med øynene lukkede. Jeg har vært veldig redd for å gjøre noen ting galt med de funksjonshemmede danserne. Å snu dem opp ned, for eksempel. At de skal falle og slå seg. Men jeg har lært at det er helt ok å tulle litt med dem. Jeg har lært å stole på mennesker som jeg ikke kjenner. Nå har jeg for eksempel lært å kjenne Vera - som tilfeldigvis bruker rullestol. Karen freaker helt ut under improvisasjoner, sier "Allah, Allah" og sånne ting. Jeg har mye mer restriksjoner. Vi lærer masse fra dem, Vera og Karen, og så kanskje vi andre lærer etterpå også. Dette var noe som jeg ikke forventet meg. (Ida)

Ikke bare i dans, men også ellers, så tror man at man må være så respektfull med funksjonshemmede. Og man tror at man alltid må være så forsiktig med noen som er funksjonshemmet. Og det var jeg og i begynnelsen, men nå på slutten så tenker jeg ikke på det i det hele tatt. [...] Den nye relasjonen som jeg har fått til mennesker med funksjonshemming har vært en virkelig "wow"-opplevelse. (Heidi) 
Jeg har lært masse. Jeg har utviklet meg i forhold til andre mennesker. Jeg har lært å uttrykke meg på en nye måte, blant nye mennesker. I begynnelsen var jeg litt urolig for at de funksjonshemmede deltakerne skulle være til hindring, men jeg har lært at de ikke er det i det hele tatt. Og jeg har sett veldig mange ulike møter. Og det har gitt meg opplevelser som har fått meg til å utvikles som danser. En følelse av tillit har utviklet seg i gruppen, jeg kjenner at jeg har fått mange nye venner. [...] jeg tenker ikke i det hele tatt på det faktum at Vera har en funksjonshemming, for eksempel. Det er ikke en hindring i det hele tatt. Og det er så flott, jeg liker det masse. (Teresa)

Dette forandrede synet hos disse danserne uten funksjonshemming er en viktig forandring som myndiggjør danserne med funksjonshemming i prosjektet på en helt ny måte. Dette forandrede synet skaper mulighet for nye, likeverdige måter å relatere på, på tvers av ulikheter og tradisjonelle, stereotype oppfattelser av grupper av mennesker. Dette åpner samtidig opp for noe nytt dansefaglig: forhandlinger om ett nytt og mer generøst rom for dans og måter å danse på. Her vil vi minne om Sandahl og Auslander $(2005,129)$ som peker på hvordan den pasientlignende rollen som ofte blir gitt til mennesker med funksjonshemming er både infantiliserende og umyndiggjørende. I intervju 3, etter at året i Danselaboratoriet er over, virker det som at Mona, Ida, Heidi og Teresa har forstått dette dypt og grunnleggende, gjennom det Mezirow (1991) kaller fundamental transformasjon av meningsperspektiver, på en måte som har forandret deres syn på mennesker med funksjonshemming dypt og gjennomgripende. Det kan virke som at de kroppslige og refleksive prosessene igangsatt $i$ Danselaboratoriet har skapt en ny relasjon mellom mennesker med og uten funksjonshemming. Dette er prosesser som inkluderer det å møtes, lytte, berøre, bli berørt og undersøke form og dynamikk i bevegelse sammen med ulikkroppede dansere, samt å diskutere det man har opplevd. Den nye relasjonen som har blitt skapt har beveget seg mot en mer dialogisk og maktsymmetrisk relasjon, og en ny form for fellesskap har oppstått i gruppen.

Men - den transformasjon av meningsperspektiver som skjedde i Danselaboratoriet er ikke lik for alle. Vera, Karen, Paul og Anna viser ikke mye forandring av meningsperspektivet "fellesskap" og ingen av dem bringer opp funksjonshemming som et meningstema i sine intervjuer. Når det gjelder Vera og Karen, så er Østerns (2009) tolkning at det rett og slett ikke finnes noen oppdagelse å gjøre for dem når det gjelder meningsperspektivet "fellesskap". De har allerede et bredt fellesskapsmeningsperspektiv. Vera og Karen har allerede et myndiggjørende og inkluderende syn på mennesker både med og uten funksjonshemming. I et av intervjuene påpeker Vera likevel at det er godt at deltakerne blir kjent med henne i dans, og ikke i hverdagen. I dansen får hun vist mer hvem hun er som Vera. Når det gjelder Paul, så forandres ikke hans fellesskapsmeningsperspektiv under året med Danselaboratoriet. Allerede fra begynnelsen er han tydelig på at dans er for alle og at det ikke spiller noen rolle hvilken kropp man har. Det er et ståsted han står fast ved gjennom prosjektet. Han kommer opprinnelig fra en storby på et annet kontinent, langt mer multikulturell enn Trondheim. Det forbauser ham ikke at ulikkroppede mennesker kommuniserer aktivt med hverandre i dans, og han inkluderer ulikkroppede mennesker i sin definisjon av potensielle dansere allerede da han starter $i$ prosjektet. Når det gjelder Anna, så tangerer hun aldri verken felleskap eller funksjonshemming i noen av sine intervjuer. Anna er isteden opptatt av spørsmål om hva dans er og hvordan dans bør undervises gjennom hele prosjektåret. Hun gjennomgår transformasjon av meningsperspektiver når det gjelder dansens estetikk og didaktikk, men ikke når det gjelder fellesskap. Hun har ikke sitt fokus på "den andre", men på sitt eget fag - dans.

Den analyse og fortolkning som er gjort i Østerns (2009) studie viser at halvparten av danserne som deltok i Danselaboratoriet da det empiriske materialet for studien ble generert visste mer og andre ting om "den andre" og om fellesskap etter at de hadde deltatt i prosjektet. Men studien viser også at 
de ulike danserne ikke gikk gjennom prosjektet som en gruppe eller på kategoriske måter. Måtene de skapte mening og forandret meningsperspektiver på i prosjektet skjedde på individuelle måter og hadde med deres livserfaringer og tidligere erfaringer med dans å gjøre. Det var for eksempel - og helt opplagt - ikke slik at dansere uten funksjonshemming opplevde og lærte på en måte og dansere med funksjonshemming på en annen. Meningstemaer og meningsperspektiver beveget seg på kryss og tvers av tradisjonelle kategorier og lot seg ikke innordne for å bekrefte for eksempel "funksjonshemmet" eller "profesjonell" som enhetlige grupper som opplever og lærer på like måter.

\section{Meningstilbud i Danselaboratoriet}

Basert på både analysen av de åtte dansernes meningsskapende prosesser i Danselaboratoriet (Østern, 2009), og våre egne erfaringer fra prosjektet, så er det mulig å si at prosjektet har meningstilbud når det gjelder transformasjon av meningsperspektivet "fellesskap". Det finns et sterkt meningstilbud om å lære om "den andre" i Danselaboratoriet. Vi mener at dette meningstilbudet er der fordi Danselaboratoriet ikke er en hvilken som helst bevegelsesaktivitet, men fordi det er en kunstnerisk og kunstpedagogisk virksomhet der ulikhet bevisst og målrettet forstås som en sentral verdi for dansen som utforskes og skapes.

$\AA$ forstå ulikhet som en impuls for meningsskaping og nye oppdagelser i Danselaboratoriet betyr at (se Østern, 2009, 280-81):

1. Danseimprovisasjon forstås som et rom for meningsskaping: en verden av muligheter.

2. Dans forstås som noe som har mangfoldige meninger. Hva dans er og kan være er under konstant reforhandling blant danserne.

3. Selve møtene mellom de ulike danserne sees som interessante. Disse møtene er selve materialet og startpunktene for det som skapes i gruppen.

4. Både estetikken og pedagogikken utvikles gjennom å aktivt bruke alles muligheter.

5. Siden møtene mellom ulike dansere er i fokus, er relasjonsbygging helt sentralt $i$ bevegelsesutforskingen.

6. Prosjektet handler ikke om funksjonshemming, men om dans. Funksjonshemming strekkes fra å være "en funksjonshemming" til å være unike muligheter til koreografisk utforsking.

7. Undervisningen skjer med et problemløsende ethos.

8. Lytting er sentralt, og ferdighet i lytting utvikles ikke minst kroppslig.

9. Alle dansere har beslutning over egen kropp og har medvirkning på det koreografiske innholdet som skapes og måtene som det skapes på.

Når ulikhet forstås om en sentral impuls for meningsskaping og nye oppdagelser i dans, så kan dette lede til endringsprosesser hos både dansere og koreograf-pedagog, ikke minst i synet på "den andre".

\section{Dansepedagoger/dansekunstnere som endringsagenter}

Danseforsker og -pedagog Leena Rouhiainen $(2008,249)$ skriver at i etiske relasjoner med andre så forandres vi også selv. Med etisk relasjon mener hun at man anerkjenner "den andres" ulikhet, men unngår å forstå "den andre" under noen som helst form for reduserende kategori, som for eksempel som "funksjonshemmet". Et meningstilbud om å bygge etiske relasjoner der man kan se forbi reduserende kategorier er klart tilstede i den estetikk og pedagogikk som Danselaboratoriet bygger på. I dette har dansekunstneren-pedagogen mulighet å være en endringsagent for både dansefeltet, dansere 
og for skole. Å begi seg inn i en transformativ estetikk og pedagogikk er en måte å forhandle om et nytt og mer generøst rom for ulikkroppede dansere, koreografer, dansepedagoger, forskere og kunstneriske ledere på scenekunstfeltet, i skole og samfunn. Dette krever likevel en refleksiv holdning fra dansekunstneren-pedagogen. Anthony Giddens (1991) definerer refleksivitet som å være oppmerksom på hva du er oppmerksom på. Refleksivitet kan også handle om å strekke seg ut etter å se det du ikke er oppmerksom på - for eksempel de muligheter til dans som en danser i rullestol har, selv om du kanskje trodde at "rullestol" automatisk utelukker fra dans.

Vi vil avslutningsvis løfte fram betydningen av den autonome og profesjonelle dansekunstnerpedagog som klarer å sette sin dansefaglighet i kontakt med de mangfoldige stemmer, kropper og kulturer som er tilstede $\mathrm{i}$ et dansende undervisningsrom. Gjennom å ikke holde fast ved etablerte, konvensjonelle og kategoriske syn på dans og hvem som kan danse, så finnes det muligheter for transformativ læring og anerkjennelse av mangfold. Dette påvirker både synet på hvem som kan danse og koreografere, og $h v a$ dans kan være. Når ulikhet forstås som en skapende kraft i danseundervisning, kan av og til magiske øyeblikk oppstå. Vi avslutter denne artikkelen med Elens fortelling om et slikt øyeblikk i møte mellom ulikkroppede dansere, der "den andre" blir forstått som aktiv, verdifull og helt nødvendig for at magiske møter skal bli til i dans:

Ett øyeblikk står fram som helt uforglemmelig for meg når det gjelder improvisasjon. Hele gruppa skulle improvisere. Plutselig fant jeg meg selv i dansende dialog med en dansekunstner jeg da ikke kjente personlig. Denne kvinnen ble jeg trygg på ved første berøring. Hun hadde en tydelig kropp, og tydelige bevegelser. Selv om hun ikke kjente meg, fantes hun ikke redd for å prøve ut ting sammen med meg. Hun lente seg på meg, la seg over meg, brukte vekten sin på meg. Dro meg i forskjellige retninger, på et tidspunkt var jeg nesten på vei ut av stolen. Hun hadde tillit til at jeg kom til å tåle det hun gjorde. For henne var jeg en fullverdig dansepartner, ikke en person hun måtte ta mer hensyn til fordi jeg satt i rullestol. Selv om vi ikke kjente hverandre, dansa vi med hverandre med en trygghet som jeg ikke hadde kjent maken til. Alt gikk helt av seg selv.

Gjennom å forstå ulikhet som en impuls for meningsskaping og nye oppdagelser i danseimprovisasjon, blir avstanden mellom forskjellige, ulikkroppede dansere gjort mindre. Man jobber sammen som ulike dansere, men på like premisser, med like muligheter og med samme verdi innenfor dansekunsten.

\section{Forfatteromtaler}

Tone Pernille Østern, PhD (Dr. of Arts in dance), er dansekunstner og koreograf på det frie scenekunstfeltet og førsteamanuensis i kunstfagdidaktikk ved Program for lærerutdanning, NTNU. Hennes doktorgrad i dansekunst er fra Teaterhögskolan i Helsingfors (nå en del av University of the Arts Helsinki). Året 2011 var hun skapende fylkeskunstner i Sør-Trøndelag fylkeskommune. For Østerns kunstneriske virke se www.dance-company.no og www.danselaboratoriet.no. Fra 2010 er hun faggruppeleder i kunstfag, mediefag og idrett ved Program for lærerutdanning, der hun også er fagansvarlig for mastergraden i kunstfagdidaktikk.

Elen Øyen (BA) er danser i Danselaboratoriet, noe hun har vært siden 2005. I 2011 begynte hun også som produsent i gruppen. Det vil si at i tillegg til å være danser, jobber hun med administrative oppgaver, som å oppdatere Danselaboratoriets webside, sende ut brev til danserne, inspisere danselokaler, drive promotering, forefallende arbeid og mye mer. Hun har i de siste årene holdt foredrag om Danselaboratoriet i ulike sammenhenger og arenaer. Hun tar for seg sin opplevelse av det å være danser i Danselaboratoriet og hva det har gjort med henne som person. Foredragene har blitt 
holdt på forskjellige dansearenaer, festivaler, konferanser, for studenter, på skoler og universiteter, for ansatte i kulturlivet og mye mer. Øyen er utdannet barnevernspedagog og juridisk kontormedarbeider.

\section{Referanser}

Benjamin, A. (2002). Making an entrance. Theory and Practice for Disabled and Non-Disabled Dancers. London: Routledge.

Giddens, A. (1991). Modernity and Self-Identity. Self and Society in the Late Modern Age. Cambridge: Polity Press.

Giorgi, A. (1985). Sketch of a Psychological Phenomenological Method. In A. Giorgi (Ed.) Phenomenology and Psychological Research. Pittsburgh: Duquesne University Press

Husserl, E. (1970). The crisis of European Sciences and Transcendental Phenomenology. An Introduction to Phenomenological Philosophy. Translated by David Carr. Evanston: Northwestern University Press.

Levinas, E. (1969). Totality and Infinity. Pittsburgh: Duquesne University Press [Først publisert på fransk i 1961 under tittelen Totalite et Infini]

Mezirow, J. (1991). Transformative Dimensions of Adult Learning. San Francisco: Jossey-Bass.

Mezirow, J. (2006/2008). An overview on transformative learning. In P. Sutherland and J. Crowther (Eds.) Lifelong learning. Concepts and contexts. Oxon and New York: Routledge

Novack, C. (1990). Sharing the Dance. Contact Improvisation and American Culture. Wisconsin: The University of Wisconsin Press.

Rouhiainen, L. (2008). Somatic dance as a means of cultivating ethically embodied subjects. In Research in Dance Education, 9(3), 241-256.

Rustad, H. (2013). Dans etter egen pipe; en analyse av danseimprovisasjon og kontaktimprovisasjonsom tradisjon, fortolkning og levd erfaring (PhD). Oslo: Norges Idrettshøyskole.

Sandahl, C. \& Auslander, P. (2005). Introduction. Disability Studies in Commotion with Performance Studies. In C. Sandahl \& P. Auslander (Eds.) Bodies in Commotion. Disability \& Performance (112). Michigan: The University of Michigan Press.

Stark-Smith, N. (1987). Editor note. Contact Quarterly, 12(2), 3.

Østern, T.P. (2009). Meaning-making in the Dance Laboratory. Exploring dance improvisation with differently bodied dancers. (Diss.) Helsinki: Theatre Academy.

Østern, T.P. (2014). Den skapende og undervisende dansekunstneren. I E. Angelo \& S. Karlsnes (red.), Kunstner eller laerer? Profesjonsdilemmaer i musikk- og kunstpedagogiske utdanning (206217). Oslo: Cappelen Damm Akademisk.

Østern, T.P. \& Øyen, E. (2014). Difference as a Creative and Critical Force in Teacher Education: Reflective Partners Teaching in and out of the Wheelchair. Journal of Dance Education, 14(3), 101-108.

Østern, T.P. \& Øyen, E. (2015, anntatt for publikasjon). Moving Change. Choreographic Practices, special issue of Dis/abilities. 